ISAHP 1999, Kobe, Japan, 12-14 August 1999

\title{
A SUSTAINABLE DEVELOPMENT POLICY FOR AN INTEGRATED FOREST PRODUCTS COMPANY
}

\author{
Sibs von Solms \\ Mondi Kraft, A Division of Mondi Ltd. \\ PO Box 1551, Richards Bay, 3900, KwaZulu-Natal, South Africa. \\ EMail: sibs_von_solms@mhs21.tns.co.za.
}

\begin{abstract}
This paper is the first in a longitudinal study of a leading South African forest products company's commitment to establish and implement a Sustainable Development policy over the next few years. The concept of Sustainable Development is introduced and a conceptual framework to illustrate the systemic nature of this concept is presented. The AHP is suggested as a tool to assist in converting this conceptual framework into a policy by prioritizing the different elements comprising Sustainable Development. The AHP is further presented as a means of ensuring that time and resource allocation, strategic planning and decisions regarding development projects are done in line with the policy. In the second part, Mondi Ltd is introduced and the environmental, economic and political sensitivities affecting this company are discussed to establish the importance of pursuing a policy of Sustainable Development.
\end{abstract}

\section{SUSTAINABLE DEVELOPMENT - A HISTORICAL PERSPECTIVE}

Although some authors already warned against the dangers of industrialization during the last years of the 19th century, it was during the 1960s that the environmental movement came of age, largely through the seminal work of Rachel Carson and her books 'The Sea Around Us' (1951) and 'Silent Spring' (1962). The movement accelerated during the 70s and 80s. In 1980, a world environmental awareness strategy was published jointly by the IUNC, UNEP and WWF in which policy principles for the maintenance of essential ecological processes and systems were documented. There has been much debate about the appropriate tools for the improvement of the environmental performance of companies. We have seen the introduction of Environmental Management Systems and their associated Standards, Environmental Auditing and Reporting and tools focusing on the environmental performance of products such as Life Cycle Assessment. However, there is now a need to go further than simply addressing the environmental performance of companies. No longer can social, economic and environmental development be seen as separate issues, their interdependence has become clearly established. In 1987 the Brundtland Report ('Our Common Future') presented us with the principle of Sustainable Development by declaring that the current generations should meet their needs without compromising the ability of future generations to meet their own. The United Nations Council for Environmental Development (UNCED) advanced this at Rio de Janeiro, in June 1992, when 179 Heads of Government signed a document called Agenda 21. It is a blueprint for Sustainable Development in the 21st century, aimed at providing a high quality environment and healthy economy for all the peoples of the world; a guide to individuals, businesses and governments in making choices for less environmentally destructive developments and in developing sustainable lifestyles.

Humanity stands at a defining moment in history. The world is confronted with worsening poverty, hunger, ill health, illiteracy and the continuing deterioration of ecosystems on which we depend for our well being. The discrepancies between the rich and poor continue. The world economy must grow to keep pace with the needs of a growing population. On the other hand, how does a company face the 
prospect that growing and being profitable could require intolerable abuse of the natural world? The current world population is estimated at approximately 6 billion of which about 1.5 billion is estimated to live in abject poverty and approximately 800 million are severely malnourished. The world population is estimated to double by the year 2030 . Without radical change, the kind of world, implied by these numbers, is unthinkable. The world cannot avoid needing sustainability in the long run. Companies should, therefore, be seeking growth through sustainability. The only way to ensure ourselves a safer, more prosperous future is to deal with environment and development issues together, in a balanced manner. We must fulfil human needs, improve living standards for all and better protect and manage ecosystems in a global partnership of Sustainable Development [Hart,1997].

\section{SUSTAINABLE DEVELOPMENT AS A SYSTEMIC APPROACH}

Linking economic, social and environmental development in a framework of Sustainable Development, presents a way forward to an improved future, but making the concept of Sustainable Development precise and easily applicable in practice has proven difficult [Greiner, et al, 1996] and companies find the concept difficult to operationalise [Welford, et al, 1998]. These problems suggest that (i) a conceptual framework is required to aid the understanding of what Sustainable Development is, and (ii) that ways should be investigated to assist firms in operationalising Sustainable Development principles into their policies and in implementing strategic plans and development projects in line with these policies.

\subsection{A Conceptual Framework}

A full discussion of different frameworks found in the literature will not be done here. Welford, et al [1998] list and discuss ten such frameworks and select a framework developed earlier by Welford [1997] as combining many people's work and bringing together many of the issues in other frameworks. This framework is presented in Table 1, and represents a good example of a conceptual framework illustrating the different elements (areas) comprising the concept of Sustainable Development. The important aspect to note, for the purposes of this paper, is the systemic nature of Sustainable Development, which implies that the different elements are interrelated and need simultaneous, holistic attention. It involves a shift from mechanistic to systemic thinking and accordingly, a new style of management known as systemic management [Callenbach, et al, 1993]. Firms are expected to have a policy in each area [Welford, et al, 1998], but what should be noted is that the six areas cannot, and should not, be addressed separately. This systemic, multi-criteria nature of the framework places two particular demands on companies attempting to implement Sustainable Development policies and actions. First, such an approach would require a complementarist approach in which the utility of different methodologies to best address different problems is recognized. Any one methodology has both strengths and weaknesses and is, therefore, not effective in solving all problems. This aspect is discussed more fully in Petkov, et al [1998]. Second, and of importance to this paper, is the need to translate the elements of the conceptual framework into a policy by prioritizing the elements in relation to each other to define the relative amount of time and resources to be allocated to the different areas. Welford, et al [1998], do not do this, and the assumption seems to be that all areas need equal attention. Stauth \& Baskind [1992] suggest three test criteria for Sustainable Development, ie Efficiency, Equity and Sustainability, and argue that a system of weighing should be applied to these different tests.

\subsection{Towards A Sustainable Development Policy}

It is generally believed that life is so complicated that to solve real problems we need to think in a complex way. Complex problems usually have many related factors. The Welford [1997] framework for sustainable development represents such a 'problem' with its 6 related factors, the so-called $6 E s$. Saaty [1992] believes that we do not need a more complicated way of thinking, but rather a more organized way, and suggests AHP as such a problem-solving framework. The hypothesis of this paper, based on preliminary evidence [von Solms, 1998], is that the AHP is the ideal vehicle to establish the 
relative importance of the $6 \mathrm{Es}$. In establishing the sustainable development policy, only the top two levels of the AHP hierarchy are to be used. The hierarchy is constructed with the six policy areas as criteria and the sub-areas as sub-criteria. The advantage of AHP in this application is that the unity of the approach is maintained while achieving a well justified policy. Addressing the elements of sustainable development in a 'balanced manner' [Greiner, et al, 1996] implies that the allocation of time and resources be balanced with the perceived importance of each element and AHP provides the facilities to do just that. If we return to the views of Stauth \& Baskind [1992] we find them stating that individuals have different values and visions for the future and that there is still no universally acceptable way to make the trade-off between efficiency, equity and sustainability. The thesis, to be investigated, is whether the AHP can assist in providing a means of deriving these weights. Tradeoffs among these dimensions must be made and the AHP considers these tradeoffs without requiring the use of a unified scale for all the dimensions [Saaty \& Vargas, 1991]. In the hierarchy, the sub-elements are included because it is felt that not only do the main elements need prioritizing but this also needs to be done for the sub-elements. The complexity of the task, which all these factors included, points to the utility of the AHP. Decision-making deserves to be promoted to a science available to all firms' management and this decision-making process must handle enough complexity to be relevant, but stay nimble enough to remain within our human capabilities. Saaty [1992] argues that the AHP fills these needs.

A pilot exercise [von Solms, 1998] was done at one of the mills of Mondi Kraft, a division of Mondi Ltd. In this exercise, 20 managers from the mill rated the 6Es using AHP. The hierarchy is shown in Table 2. The group was divided into two sub-groups, viz managers in areas where ISO 9002 was fully implemented (called the ISO group) and managers in areas where this quality management standard was either not implemented yet, or only partially implemented (Non-ISO group). The results, shown in Table 1, indicated a degree of agreement but some interesting priority differences were also recorded. For example, Ethics was rated highest by the Non-ISO group, while being rated only fourth by the ISO group. Such differences, observed in a sample that could be seen as homogeneous, suggest that more pronounced differences would be found in a wider, more heterogeneous, sample. This problem necessitates that the process be taken further and expanded in three ways. First, the sample will be expanded laterally by involving all mills across the company's divisions. Second, the sample will also be expanded vertically by including both managers and employees from lower ranks. Third, the similarities and differences will be more extensively evaluated to present top management with a clear picture of the priorities, across a wide spectrum of employee perceptions, on which to base the final policy. The value of such participatory approaches to policy development is widely recognized [Mullins, 1993] [O'Reilly, 1991] and the utility of AHP in similar approaches indicated [von Solms, 1998].

\subsection{Implementing the Sustainable Development Policy}

Once the Sustainable Development Policy has been established this policy should be implemented and operationalised. Again, the need for a mixing of tools and techniques are important but not addressed here. Two aspects are suggested to best be achieved using AHP. First, the forward and backward processes of AHP for Planning [Saaty \& Vargas, 1991] should be used in Strategic Planning. Using the elements (6Es) as guidelines, the strategic plans can be kept in line with the accepted policy. Second, the AHP provides the tool to analyze alternative development projects (as alternatives in the hierarchy) to choose those projects best fitting the priorities set for Sustainable Development. In this way, AHP can be used not only to set the policy priorities but also to ensure long-term implementation of these principles and priorities both in strategic planning and decisions on actual development projects.

\section{ORGANISATIONAL CONTEXT OF THE RESEARCH}

Mondi Ltd is one of the two largest forest products manufacturing and distributing companies in South 
Africa. The South African economy is characterized by an oligopolistic structure in which numerous companies are privately owned by a handful of major Multi National Corporations. In Mondi Ltd's case, the principal shareholder is Anglo American Corporation of South Africa (AAC). Mondi Ltd is, in turn, a large international company with shareholder funds exceeding R3,8 billion ( $\$ 630$ million) in 1996/7. Mondi Ltd's international interests include mills in Brazil, Austria and the United Kingdom. The company pursues a diversified strategy and operates various subsidiaries with interests in Forests, Timber Products, Copy Paper, Cartonboard, Recycled Paper, and Kraft Pulp and Linerboard.

\subsection{Environmental Sensitivities of Forest Products Manufacture}

Several, environmental sensitivities exist in regards to the forest products industry. First, the issue of natural forest depletion was long the main criticism of any producer of pulp, paper or timber products. With the increased use of cultivated forest specific for the use of the forest products industry and the fact that this represents a renewable resource, this critique has largely disappeared. The issue is, however, not entirely over and the efforts of the Forest Stewardship Council (FSC) attest to this. Certification of forests to determine the standards of forest cultivation and sustainability is a new and important tool to audit and report on the standards of forest management. Second, the bleaching of pulp to produce the pulp required for copy papers has been under scrutiny since the link between the use of elemental Chlorine and toxic substances such as the Dioxins and Difurans were shown to exist. This led to changes in bleaching processes, the use of Chlorine Dioxide as a Chlorine substitute in the so-called ECF processes and the increased use of Ozone and Hydrogen Peroxide as bleaching agents. Third, the malodorous gases produced by the Kraft cooking process have long been a problem to mills using this particular process. Although these gases have no negative effect on either human, animal or plant health, at the concentrations normally released, the degradation of the quality of life of people living in near proximity of Kraft pulp mills is seen as problematic. The extreme sensitivity of the human nose to these so-called Reduced Sulphur Gases, implies that neighboring communities often detect even small accidental emissions.

\subsection{Political Sensitivities of Sustainable Development}

Several, political sensitivities are fundamental to Sustainable Development. These sensitivities include the labour issues of empowerment, worker participation and equal opportunities and economic issues like the increase of employment and the rights of local/indigenous peoples. Equity has also to be tackled at the level of the firm, however. Flatter forms of industrial organization can empower workers and increase their decision-making powers, increasing democracy in the workplace and a sense of responsibility towards a company's environmental performance. This requires a more socially responsible approach to doing business which values workers as an integral and valuable part of the organization rather than a resource to be hired and fired as external market conditions alter. These are all worldwide implications and need to be given serious attention wherever man endeavours to improve the sustainability of his actions. In post-apartheid South Africa, however, some of these issues are, furthermore been given special attention in the process of transformation now prevalent in this country. The South African government is one of the signatories to the Agenda 21 document and has committed itself to furthering sustainable development principles in national policies. One of these policy areas is Forest Management and sustainability principles are included in the Policy for Forest Development in South Africa.

\subsection{Economic Sensitivities of Sustainable Development}

In the last few years, there has been growing interest in the relationship between Sustainable Development and financial investment. Increasingly, investors are seeking funds that employ ethical, social and environmental criteria in shaping their portfolios. This trend has been encouraged by the introduction of tax incentives in this area. Companies, investors and other parties are positioning themselves within this trend, each from their own particular perspective [Corten, et al, 1998]. 
Companies listed on the stock exchange are asking themselves - What are the implications of Sustainability for our company's operations and its appeal to investors? Institutional investors are starting to ask themselves whether Sustainability will affect their investment portfolio and other parties, governmental and non-governmental, are considering whether they can help accelerate developments through the phenomenon of investment.

\subsection{Sustainable Development and Mondi Ltd}

From the sensitivities highlighted above, it should be clear that the formulation of a Sustainable Development policy is of great importance to Mondi Ltd, as indeed to many other companies. As both a local and international supplier of forest products, the environmental impacts of these processes cannot be ignored. In the political climate of the international community, but specifically as a concerned employer in South Africa, paying attention to the political sensitivities in Sustainable Development are of paramount importance to Mondi Ltd. The financial investment aspects are not yet as advanced in South Africa as indicated above, but this may change soon and, furthermore, Mondi's international activities demand that international trends be monitored and accepted where necessary. Mondi management has shown commitment over the last decade to development and improvement in several areas. There were the efforts in quality management, indicated by the ISO 9002 certifications of the different Divisions. Environmental management practices were included, attested to by the ISO 14001 and FSC certifications of many of Mondi's Divisions. Employee development too was actively pursued in many human resource interventions, including training, teambuilding and organizational development. The way forward, argued in this paper, is to integrate and expand these different activities under the umbrella concept of Sustainable Development. The preliminary evidence indicates that this can best be achieved by using AHP in policy formulation, strategic planning and development project selection.

\section{CONCLUSION}

This paper argued that the world economy must grow to keep pace with the needs of a growing population without undue damage to the environment. The world, therefore, cannot avoid needing sustainability in the long run. This paper further indicated that Sustainable Development would require a systems approach within which multi-criteria tradeoff decisions are required and presented the AHP as the ideal vehicle to achieve this. The paper is the first in a longitudinal Action Research study in which this challenge is accepted and the theories and tools, described above, are simultaneously used and tested in the actual organizational setting of Mondi Ltd. The outcomes will not only benefit the company in their efforts to play a leading role in sustainable development activities in South Africa but is also a novel research project in which the three concepts of Sustainable Development, Creativity and AHP are investigated and their relationships explicated.

\section{REFERENCES}

Callenbach, E; Capra, F; Goldman, L; Lutz, R \& Marburg, S; (1993); Eco-Management: The Elmwood Guide to Ecological Auditing and Sustainable Business; Berrett-Koehler Publ; San Francisco, CA.

Corten, FGP; Metz, D; van Soest, JP \& Vervoordeldonk, R; (1998); Environmental Information for Investors; A Report Published by the Association of Investors for Sustainable Development; Culemborg, The Netherlands.

Greiner, C; Radermacher, FJ \& Rose, T; (1996); Contributions of the Information Society to Sustainable Development; A Report Published by Reimann; Biberach, Germany.

Hart, SL; (1997); Beyond Greening: Strategies for a Sustainable World; Harvard Business Review; $\mathrm{Jan} / \mathrm{Feb} ; 67-76$.

Mullins, LJ; (1993); Management and Organisational Behaviour; $3^{\text {td }}$ Edition; Pitman Publ; London.

O'Reilly, C; (1991); Corporations, Culture and Commitment: Motivation and Social Control in Organizations; in Steers, RM \& Porter, LW (Eds); (1991); Motivation and Work Behavior; $5^{\text {th }}$ 
Edition; McGraw-Hill; New York, NY

Petkov, D; McEwan, T \& von Solms, S; (1998); Moving Towards Compliance with Standards for Environmental Protection - An Example of Mixing Approaches to 'Messy' Problems; Proceedings European meeting on Cybernetics \& Systems Research; Vienna.

Saaty, TL; (1990); Decision Making for Leaders: The AHP for Decisions in a Complex World; $2^{\text {nd }}$ Edition; RWS Publ; Pittsburgh, PA.

Saaty, TL; (1992); A Natural Way to Make Momentous Decisions; J of Sci \& Ind Res 15; Aug./Sept.; 561-571.

Saaty, TL \& Vargas, LG; (1991); Prediction, Projection and Forecasting: Applications of the AHP in Economics, Finance, Politics, Games \& Sports; Kluwer Academic Publ; Boston, MA.

Stauth, RB \& Baskind, PH; (1992); Resource Economics; in Fuggle, RF \& Rabie, MA (Eds); (1992); Environmental Management in South Africa; Juta \& Co Ltd; Johannesburg.

von Solms, S; (1998); A Systems Approach to TQM for Integrating Quality and Environmental Management; Unpublished MCom Thesis; University of Natal, Pietermaritzburg; South Africa.

Welford, RJ; (1997); Hijacking Environmentalism: Corporate Responses to Sustainable Development; Earthscan; London.

Welford, RJ; Young, W \& Ytterhus, B; (1998); Towards Sustainable Production and Consumption: A Literature Review and Conceptual Framework for the Service Sector; Eco-Mgmt Aud 5; 3856.

\section{TABLE 1. POLICY AREAS FOR SUSTAINABLE DEVELOPMENT [WELFORD,1997]}

\begin{tabular}{|l|l|c|c|}
\hline Policy Area & \multicolumn{1}{|c|}{ Sub-areas } & $\begin{array}{c}\text { AHP Ratings } \\
\text { Group 1 }\end{array}$ & $\begin{array}{c}\text { AHP Ratings } \\
\text { Group 2 }\end{array}$ \\
\hline Environment & $\begin{array}{l}\text { Life Cycle Assessment } \\
\text { Environmental Management Systems and Audits } \\
\text { Functionality Assessment } \\
\text { Resource Management }\end{array}$ & 0.204 & 0.137 \\
\hline Empowerment & $\begin{array}{l}\text { Teambuilding } \\
\text { Participation } \\
\text { Equal Opportunities } \\
\text { Declaration of Rights }\end{array}$ & 0.091 & 0.150 \\
\hline Economics & $\begin{array}{l}\text { Profits/surplus } \\
\text { Employment } \\
\text { Quality } \\
\text { Long-term Financial Stability and Investment }\end{array}$ & 0.207 & 0.202 \\
\hline Ethics & $\begin{array}{l}\text { Transparency of Objectives } \\
\text { Openness to Concerns } \\
\text { Honesty } \\
\text { Values Statements }\end{array}$ & 0.181 & 0.217 \\
\hline Equity & $\begin{array}{l}\text { Fair Trade Policy and Activity } \\
\text { End-price Auditing } \\
\text { Development Aid } \\
\text { Sponsorship }\end{array}$ & 0.075 & 0.082 \\
\hline Education & $\begin{array}{l}\text { Training } \\
\text { Customer Information } \\
\text { Community Involvement } \\
\text { Campaigning }\end{array}$ & 0.243 & 0.213 \\
\hline
\end{tabular}

TABLE 2. AHP HIERARCHY: POLICY AREAS FOR SUSTAINABLE DEVELOPMENT

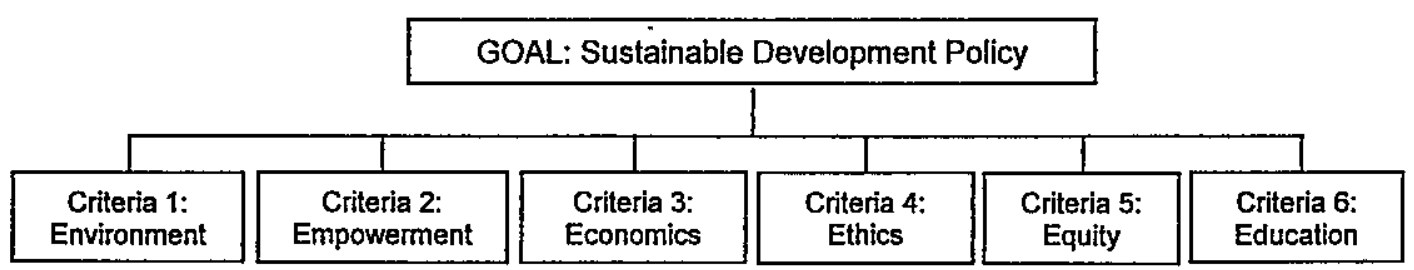

